\title{
Oreste Ristori. Uma aventura anarquista
}

\author{
Bruno Corrêa de Sá e Benevides.
}

ROMANI, Carlo. Oreste Ristori. Uma aventura anarquista. São Paulo: Annablume, 2002.

O livro Oreste Ristori - uma aventura anarquista, de Carlo Romani, é uma obra de fôlego que tem por objetivo expor a trajetória biográfica do anarquista italiano, Oreste Ristori, que após se refugiar na Argentina por um breve período (1901-1903), migrou para o Brasil (1903) permanecendo no país por longos anos, passando a figurar, em razão da sua intensa militância, ao lado de grandes nomes do movimento operário brasileiro, em especial entre os anarquistas dos primeiros anos do século XX, até o seu retorno à Itália na década de 1940.

A partir de uma análise profunda e de incansável consulta a um vasto repertório documental (cartas pessoais, ofícios de instituições policiais, inquéritos e periódicos diversos - inclusive de própria autoria de Ristori), consultados em diversos arquivos, tanto no Brasil como na Argentina e na Itália, Romani remonta a origem, a trajetória biográfica e os principais acontecimentos em que este italiano anarquista esteve envolvido, ressaltando as prisões as quais foi submetido ao longo de sua vida como militante, as condenações criminais, sua atuação como propagador dos ideais anarquistas, além de conceder, também, atenção às ações cotidianas como o seu gosto pela música e pela poesia e a profunda paixão por sua companheira Mercedes.Em seguida, o autor descreve a posição de Oreste Ristori dentro do anarquismo, salientando seu percurso de transição entre uma vertente individualista, que vai gradualmente sofrendo influência de uma concepção anárquica mais associativa, até romper, em definitivo, a partir de 1920, com a utopia anarquista se aproximando do comunismo.

Buscando realizar uma cronologia da vida de Ristori, o autor divide a obra em quatro capítulos que se desdobram em outros subcapítulos. A narrativa, tal qual um filme, começa de trás para frente iniciando com o fuzilamento sumáriode Oreste Ristori por fascistas que deu fim à sua vida, em 1943, na Itália, retomando em seguida a cronologia desde o seu nascimento. $\mathrm{O}$ texto possui uma cadência peculiar, com grande traço literário, porém sem perder de vista o rigor metodológico e historiográfico.

O primeiro capítulo é uma apresentação do personagem central e da sua origem social. Nele passamos a conhecer um pouco sobre a realidade cotidiana da cidade de Empoli, na Itália, onde Oreste nasceu em 1874, trabalhou e obteve, pela primeira vez, o contato com as ideias anarquistas. Em seguida, no mesmo capítulo, o autor aproveita a ocasião para relatar o período em que Oreste esteve recolhido, em razão de cumprimento de pena, no domicílio coatto (espécie de prisão exclusiva para determinados crimes) após condenações por envolvimentos em atividades consideradas subversivas, além de relatar a sua passagem em diversos países vizinhos, como por exemplo a França.

O segundo capítulo se dedica à compreensão do período em que Oreste viveu refugiado na Argentina e a sua breve passagem pelo Uruguai. Sua produção textual durante a sua vivência na região platina, principalmente como redator dos jornais 'La Protesta Humana' e 'L'Avvenire', é profundamente analisada. Em 1902, entrou em sérias divergências com alguns anarquistas e socialistas argentinos discordando sobre a forma de organização do movimento operário naquela região, além de criticar a ação grevista intentada no país naquele mesmo ano. Tal episódio limitou o espaço de atuação de Ristori obrigando-o a se mudar para o Brasil por volta do final de 1903.

O terceiro capítulo cuidou especialmente da passagem deste anarquista italiano no Brasil, especialmente em São Paulo, cidade em que abrigava maior colônia de italianos no país, sendo grande reduto de proeminentes nomes do anarquismo ligados ao movimento operário nos primeiros anos de 1900. Já no Brasil, tem contato com dois velhos conhecidos: Gigi Damiani e Alessandro Cerchiai, que, assim como Ristori, possuem grande aproximação ideológica com as propostas anarquista de Errico Malatesta. Ainda neste capítulo, o autor menciona o Jornal 'La Battaglia',

Graduando em História pela Universidade Federal do Estado do Rio de Janeiro - UNIRIO. Está sob orientação do Professor Doutor Carlo Maurizio Romani (UNIRIO). 
editado no Brasil por Oreste Ristori a partir de 1904, além de reservar espaço às críticas elaborada por Ristori ao movimento sindical entre os anarquistas. $\mathrm{O}$ capítulo também traz um subcapitulo tratando especialmente das Escolas Modernas e da experiência pedagógica encetada por Oreste e seu grande companheiro Angelo Bandoni (ao organizarem a Escola Libertária Germinal). Ainda nesta seção, é relatado o momento em que Oreste vai à Buenos Aires e tem contato com a sua futura companheira - Mercedes.

Por fim, o quarto e último capítulo vem destacando o encerramento da trajetória de Oreste Ristori no Brasil, a sua adesão à tese do maximalismo (tese que significou a união de todos os movimentos operários em prol da revolução social) e a sua participação na frente Única contra o fascismo. Relata ainda a passagem que teve na Espanha, na França, até o seu definitivo regresso à sua cidade natal, Empole, na Itália, onde foi sentenciado e executado sumariamente à morte por fuzilamento.

Apartir da micro-história, Carlo Romani apresenta um importante trabalho acadêmico resgatando não apenas a trajetória biográfica de Oreste Ristori, como também o ambiente social em que este anarquista viveu, sobretudo durante a sua estada no Brasil.

Neste sentido, pode-se dizer que o presente livro é de leitura obrigatória para aqueles que desejam se aprofundar no estudo sobre o anarquismo no Brasil nos seus anos iniciais, além, é claro, de ser conteúdo indispensável sobre a biografia do anarquista italiano 